\title{
Peranan Guru Dalam Menerapkan Keterampilan Bertanya Di SD Negeri 56 Banda Aceh
}

\author{
Israwati \\ Dosen PGSD FKIP Unsyiah \\ israpaud@unsyiah.ac.id
}

Adnan

Dosen PGSD FKIP Unsyiah

Adnanabdullah408@gmail.com

\section{Husin \\ Husin@unsyiah.id}

Farha

Dosen PGSD FKIP Unsyiah

Farha2809@yahoo.com

\author{
Rahayu \\ PGSD FKIP Unsyiah \\ rahayuayu@gmail.com
}

\begin{abstract}
Abstact
The role of teachers in applying questioning skills is carried out during learning The purpose of this study is to determine the role of teachers in applying questioning skills, obstacles and solutions in applying questioning skills in SD Negeri 56 Banda Aceh. Implementation, obstacles and solutions that are studied in this study are the roles that teachers do in applying questioning skills during learning. This research uses a qualitative research approach with descriptive research type. The subjects in this study were first grade to sixth grade teachers at SD Negeri 56 Banda Aceh. Data collection techniques are interviews, observation and documentation. Data analysis techniques used in this study were data analysis, data models (data display) and conclusion drawing / verification. The data validity technique used in this study is source triangulation. The observation of researchers at SD Negeri 56 Banda Aceh can be concluded that the teacher's questioning skills are the most frequent and most important activities carried out in the learning process. The ability to ask is the main ability that must be possessed by the teacher because asking is a tool for teaching. Because almost every stage of learning the teacher is required to ask questions, and the quality of the questions asked by the teacher will determine the quality of student answers. Giving questions will help students learn mentally and be more perfect in receiving information so students participate actively during the learning process.
\end{abstract}

Keywords: Role, Questioning Skills

\section{Pendahuluan}

Pendidikan merupakan salah satu faktor penunjang keberhasilan pembangunan yang sangat penting. Dalam sejarah pertumbuhan masyarakat, pendidikan senantiasa menjadi perhatian utama dalam rangka memajukan kehidupan generasi demi generasi sejalan dengan tuntutan kemajuan masyarakatnya. Sangat wajar jika 
kemajuan suatu bangsa dapat dilihat dari seberapa besar perhatian bangsa tersebut terhadap pendidikan.

Dalam proses pendidikan, guru merupakan sosok yang sangat penting. Melalui kemampuan guru, pencapaian tujuan pembelajaran dapat maksimal terlaksanakan. Mulyasa (2006:35) mengatakan guru memiliki andil yang sangat besar terhadap keberhasilan pembelajaran di sekolah. Guru sangat berperan dalam membantu perkembangan peserta didik untuk mewujudkan tujuan hidupnya secara optimal. Minat, bakat, kemampuan dan potensi-potensi yang dimiliki oleh peserta didik tidak akan berkembang secara optimal tanpa bantuan guru.

Roestiyah (2012:129) mengatakan, jika guru melontarkan teknik tanya jawab atau memberi pertanyaan mempunyai tujuan, agar siswa dapat mengerti atau mengingatingat tentang fakta yang dipelajari, didengar ataupun dibaca, sehingga mereka memiliki pengertian yang mendalam tentang fakta itu. Diharapkan pula dengan tanya jawab itu mampu menjelaskan langkah-langkah berpikir atau proses yang ditempuh dalam memecahkan soal/masalah sehingga jalan pikiran anak tidak meloncat-loncat.

Rangkaian kegiatan pembelajaran yang dilakukan dalam kelas untuk menumbuhkan aktivitas dan partisipasi siswa salah satu caranya dengan merangsang siswa untuk mengajukan pola pikir yang di miliki oleh seorang siswa. Dalam dunia pendidikan, siswa belum banyak terangsang untuk mengajukan pertanyaan dari materi yang dipelajari, karena siswa tidak terlatih dalam mengajukan pertanyaan, siswa kurang percaya diri dengan konsep yang dimiliki atau siswa tidak diberi kesempatan bertanya oleh guru. Selain itu guru juga dapat mengajukan pertanyaan kepada siswa untuk memancing keaktifan siswa.

Dalam proses pembelajaran strategi yang ditetapkan oleh guru di kelas hendaknya memperhatikan keaktifan siswa dalam belajar. Siswa diharapkan tidak belajar hanya dari guru saja tetapi juga belajar dari lingkungan sekitarnya, misalnya dari teman, orang tua ataupun media. Siswa dapat memperoleh ilmu pengetahuan di manapun berada. Siswa yang aktif mempunyai peluang yang besar untuk keberhasilan belajarnya dibandingkan dengan siswa yang pasif dan hanya menerima saja.

Guru bertanya untuk mengetahui pemahaman siswa, untuk mendorong siswa berpikir, dan untuk menyusun serta mengarahkan pembelajaran. Pertanyaan digunakan oleh guru sebagai alat diagnosa dalam menentukan tingkat pengajaran untuk membantu siswa mengingat aturan-aturan, sementara sebagian pertanyaan memungkinkan siswa untuk mengekspresikan perasan serta pendapat mereka sendiri. Pertanyaan merupakan metode yang utama untuk mengetahui pemahaman siswa. Pertanyaan bisa diberikan dalam suatu rangkaian cepat untuk membahas ulang isi pelajaran atau digunakan sebagai evaluasi akhir dari pembelajaran siswa. Mempelajari seni bertanya pertanyaan yang tepat di waktu yang tepat dan dengan cara yang tepat bisa merupakan salah satu dari aspek-aspek mengajar yang paling menantang.

Peneliti melakukan pra-observasi di SD Negeri 56 Banda Aceh. Saat melakukan observasi di SD tersebut, peneliti menemukan permasalahan dalam pembelajaran, guru masih kurang memberikan pertanyaan saat mengajar, dan terlalu mengedepankan materi sehingga guru tidak mengetahui apakah siswa sudah mengerti ataupun belum dengan tidak menanyakan pertanyaan dan tidak memberi kesempatan siswa untuk bertanya. Diharapkan guru memberikan pertanyaan di selasela pembelajaran sehingga siswa dapat terlatih untuk menemukan jawaban secara cepat dan tepat, dan bagi guru juga dapat menimbang pengetahuan yang dimiliki siswa sehingga lebih memudahkan dalam menyampaikan materi yang tidak terlalu berat apabila siswa terasa belum terbiasa untuk pembelajaran yang berat. Dengan 
memberikan pertanyaan guru dapat mengulang kembali materi sulit yang belum di mengerti siswa.

Berdasarkan latar belakang masalah yang telah dikemukakan di atas, guru harus memiliki upaya yang dilakukan guru untuk menerapkan keberanian siswa untuk bertanya dengan menggunakan keterampilan dasar seorang guru. Oleh karena itu penulis tertarik melakukan penelitian dengan judul "Peranan Guru dalam Menerapkan Keterampilan Bertanya di SD Negeri 56 Banda Aceh"

Rumusan masalah dalam penelitian ini adalah (1) Bagaimanakah peranan guru dalam menerapkan keterampilan bertanya pada siswa di SD Negeri 56 Banda Aceh? (2) Apa saja hambatan guru dalam menerapkan keterampilan bertanya pada siswa di SD Negeri 56 Banda Aceh?.

\section{Metode}

Pendekatan dalam penelitian ini adalah pendekatan kualitatif. Dengan jenis penelitian yang digunakan adalah deskriptif. Peneliti menggunakan jenis penelitian ini karena peneliti ingin mendeskripsikan suatu fenomena sesuai dengan keadaan yang sebenarnya dialami oleh subjek penelitian dan menyajikan data tersebut dalam bentuk kata-kata.

Lokasi penelitian dilakukan di SD Negeri 56 Banda Aceh beralamatkan di jalan Tengku Iskandar Desa Lamglumpang Kecamatan Ulee Kareng Banda Aceh. Populasi dalam penelitian ini adalah seluruh guru kelas di SD 56 Banda Aceh yang berjumlah 12 orang. Sedangkan sampel sebanyak 6 orang dari setiap tingkatan kelas. Pengambilan sampel dilakukan dengan cara purposive sampling. Zuriah (2009:124) menjelaskan bahwa dalam purposive, cara mengambil subjek penelitian didasarkan atas ciri-ciri tertentu yang dipandang mempunyai sangkut paut yang erat dengan populasi yang diketahui sebelumnya. Peneliti mengambil subjek satu guru pertingkat karena peneliti ingin melihat peranan guru dalam keterampilan bertanya setiap tingkatan.

Teknik pengumpulan data dilakukan dengan observasi, wawancara dan dokumentasi. Teknik analisis data yang digunakan adalah teknik analisis data kualitatif berdasarkan teori Bogdan dan Biklen yang telah dirumuskan Sugiyono (2015:334) adalah analisis data adalah proses mencari dan menyusun secara sistematis data yang diperoleh dari hasil wawancara dan bahan-bahan lain sehingga dapat mudah dipahami, dan temuannya dapat diinformasikan kepada orang lain.

Analisis data dilakukan dengan mengorganisasikan data, menjabarkan ke dalam unitunit, melakukan sintesa, menyusun pola, memilih mana yang penting dan yang akan dipelajari dan membuat kesimpulan yang dapat diceritakan kepada orang lain.

\section{Hasil}

Observasi dilakukan oleh peneliti dengan mengamati siswa selama proses pembelajaran berlangsung selama dua kali pengamatan dimulai tanggal 17 Juli 2017 sampai dengan 18 Juli 2017 dengan alokasi waktu masing-masing 1 X 40 menit (1 jam pelajaran) setiap 6 kelas per harinya. Selama proses pembelajaran peneliti mencatat hal penting dan sesering apa guru menggunakan keterampilan bertanya selama pembelajaran. Peneliti juga memperhatikan sebanyak mana anak mampu menjawab pertanyaan dari guru.

Hasil Observasi Pelaksanaan Keterampilan Bertanya 
Berdasarkan hasil pengamatan peneliti siswa masih belum responsif menanggapi pertanyaan yang diajukan guru karena pembahasan materi untuk hari ini siswa belum mengerti, tetapi untuk pertanyaan apersepsi sebagian siswa sudah responsif untuk menjawab. Indikator selama pembelajaran yaitu:

a. Oral activities, yaitu aktivitas belajar siswa bertanya kepada teman/guru, menjelaskan kembali materi yang telah disampaikan guru maupun teman, terlibat dalam melakukan diskusi kelompok dan merespon/menjawab pertanyaan dari guru maupun teman.

b. Listening activities, yaitu aktivitas belajar siswa dalam melakukan diskusi kelompok. Diskusi kelompok sangat cocok bagi siswa, karena siswa dapat saling membantu dan peduli terhadap anggota yang lain.

c. Mental activities, yaitu aktivitas belajar siswa menanggapi pertanyaan, memecahkan masalah, dan membuat keputusan. Aktivitas menanggapi pertanyaan sering dilakukan oleh siswa yang berkemampuan tinggi dan siswa yang berkemampuan sedang.

d. Writing activities, yaitu aktivitas belajar siswa untuk menyalin/mencatat materi pembelajaran, menulis pertanyaan dan mengerjakan tugas pembelajaran.

e. Visual activities, Aktivitas belajar siswa dalam visual activities adalah memperhatikan penjelasan teman/guru. Hasil observasi dapat dikatakan bahwa siswa mempunyai antusias dan semangat yang tinggi untuk memperhatikan penjelasan guru maupun temannya sendiri.

f. Emosional activities, Aktivitas belajar siswa berani atau bersemangat dalam mengikuti kegiatan pembelajaran.

\section{Hasil Wawancara}

Wawancara dilakukan kepada seluruh guru yang menjadi sampel dengan mengajukan beberapa pertanyaan.

1. Bagaimana tingkat kemampuan siswa dalam pembelajaran di Kelas $\mathrm{I} / \mathrm{II} / \mathrm{III} / \mathrm{IV} / \mathrm{V} / \mathrm{VI}$ ?

Berdasarkan hasil analisis data wawancara yang dilakukan peneliti di kelas I-VI, dapat disimpulkan bahwa tingkat kemampuan siswa dalam pembelajaran di SD N 56 Banda Aceh masing-masing kelas sudah bagus dan baik, respon pembelajaran telah di terima dengan baik oleh siswa.

2. Apakah siswa memperhatikan penjelasan materi pelajaran yang Bapak/Ibu sampaikan?

Berdasarkan hasil analisis data wawancara yang dilakukan peneliti di lapangan yaitu di SDN 56 Banda Aceh, dapat disimpulkan bahwa selama pembelajaran berlangsung siswa sudah memperhatikan penjelasan guru namun penangkapan mereka yang berbeda-beda. Untuk siswa kelas rendah yang berada pada tahap bermain. Pada masa ini guru harus menyiapkan proses pembelajaran dengan menarik perhatian siswa dengan bermain sehingga secara sekaligus mereka bisa mendengarkan pembelajaran. sedangkan untuk siswa kelas tinggi mereka sudah lebih terfokus pada proses pembelajaran.

3. Apakah setiap tugas yang diberikan oleh Bapak/Ibu selalu dikerjakan dengan baik oleh siswa?

Secara keseluruhan hasil wawancara guru kelas I hingga kelas VI, siswa di SD Negeri 56 Banda Aceh sudah dapat mengerjakan tugas dari guru dengan cukup baik, dan apabila ada yang kurang mengerti, mereka akan bertanya kepada guru. Untuk siswa kelas rendah guru selalu memberikan bimbingan dan memantau setiap individu saat pemberian tugas. Hal ini dikarenakan ada beberapa siswa yang malu dengan temannya, atau bertanya di depan umum sehingga di saat guru berada di sampingnya akan lebih memudahkan siswa bertanya. 
4. Apakah Bapak/Ibu memberikan catatan tertulis kepada siswa tentang materi yang Bapak/Ibu sampaikan ? dan apakah siswa pernah dilatih untuk membuat catatan dengan bahasa mereka sendiri?

Hasil analisis data wawancara yang dilakukan di SDN 56 Banda Aceh selama pembelajaran berlangsung ada guru yang mewajibkan siswa untuk mencatat, ada pula guru yang mengikuti langkah pembelajaran di kurikulum baru sehingga mereka mengabaikan catatan pribadi siswa. Untuk anak kelas I siswa hanya di kenalkan dengan berbagai hal yang ada di lingkungan dan menuliskan kata per kata sebagai latihan dalam menulis.

5. Menurut Bapak/Ibu, apakah teknik keterampilan bertanya diterapkan dengan baik di kelas?

Hasil analisis wawancara yang dilakukan di SDN 56 Banda Aceh, selama pembelajaran berlangsung dengan menggunakan teknik bertanya sudah membuat pembelajaran berjalan dengan baik, dan lebih membuat anak mengerti dan paham terhadap pembelajaran. Jika anak belum paham tentu dia akan bertanya, dan jika dia sudah belajar dirumah sebelumnya, dia akan lebih paham tentang apa yang perlu di tanyakan selama pembelajaran tentang hal-hal yang belum dimengerti.

6. Sebagai seorang guru, apakah upaya Bapak/Ibu lakukan untuk meningkatkan aktivitas belajar?

Hasil analisis data wawancara yang dilakukan di SDN 56 Banda Aceh, selama pembelajaran berlangsung guru menggunakan banyak cara untuk meningkatkan aktivitas belajar siswa, dengan cara-cara yang sesuai dengan tingkat siswa dan pembelajaran yang akan disampaikan. Cara yang dilakukan oleh guru antara lain mengajak siswa untuk bernyanyi dan menari sebagai pengantar pembelajaran sesuai dengan materi yang akan di belajarkan sehingga akan menarik siswa untuk belajar dan membuat pembelajaran lebih menyenangkan. menunjukkan gambar-gambar yang menarik yang mampu menggugah rasa penasaran siswa, menampilkan video pembelajarn menggunakan media animasi dan lain sebagainya. Cara-cara tersebut merupakan upaya yang dilakukan untuk membangkitkan minat sisw dalam proses pembelajaran.

7. Jika ada materi yang kurang dimengerti oleh siswa, apakah siswa tersebut mencoba untuk berdiskusi dengan siswa lainnya ?

Hasil wawancara menunjukkan bahwa pelaksanaan peranan guru dalam menerapkan keterampilan bertanya selama pembelajaran dapat dilihat dari bagaimana guru menerapkan keterampilan bertanya. Dan melalui pengamatan guru kepada siswa selama pembelajaran, siswa mencoba untuk berdikusi dengan siswa lain mengenai hal yang belum di mengerti. Selain itu siswa juga bertanya mengenai hal yang belum di mengerti kepada guru. Guru mempunyai teknik tersendiri agar materi mudah di pahami, seperti meminta anak untuk mengerjakan soal di papan, atau mendatangi siswa langsung dan memberikan penjelasan. Ada beberapa siswa terkadang malu bertanya kepada guru, sehingga siswa tersebut dapat bertanya kepada eman atau tutor sebaya.

8. Apakah Bapak/Ibu memberikan pertanyaan, bagaimana respon siswa terhadap pertanyaan Bapak/Ibu?

Hasil wawancara menunjukkan bahwa pelaksanaan peranan guru dalam menerapkan keterampilan bertanya selama pembelajaran dapat dilihat dari bagaimana guru menerapkan keterampilan bertanya. Hasil analisis data wawancara yang dilakukan di SDN 56 Banda Aceh, dapat disimpulkan bahwa selama pembelajaran berlangsung ada siswa memberikan respon yang baik setiap guru bertanya namun ada beberapa siswa yang masih belum baik dalam 
merespon, terkadang ada yang diam saja. Anak yang merespon merupakan anak yang menegerti pertanyaan dari guru menjawab dengan penuh percaya diri sedangkan ada anak yang diam masih kurang paham terhadap materi yang diajarkan. Anak-anak yang kurang dalam pembelajaran akan diberikan pembelajaran pengulangan agar anak segera mengerti.

\section{Hambatan dan Solusi}

1. Apakah siswa merasa senang selama pembelajaran?

Hasil wawancara menunjukkan bahwa pelaksanaan peranan guru dalam menerapkan keterampilan bertanya selama pembelajaran dapat dilihat dari hambatan dan solusi guru dalam pembelajaran. Siswa kelas rendah dalam proses pembelajaran sudah senang dalam belajar hal ini karena guru mencipktakan proses pembelajaran yang kreatif yang bisa membangkitkan minat belajar anak. Guru menampilkan gambar-gambar yang menarik, menyanyikan lagu di awal pembelajaran yang disesuaikan dengan materi pembelajaran, menari mengikuti irama. Untuk siswa kelas tinggi guru menggunakan metode yang berbeda-beda setiap materi agar siswa tidak merasa bosan.

2. Bagaimana cara Bapak/Ibu memberi motivasi/stimulus kepada siswa agar siswa aktif bertanya?

Hasil wawancara menunjukkan bahwa pelaksanaan peranan guru dalam menerapkan keterampilan bertanya selama pembelajaran dapat dilihat cara guru memberi motivasi dan stimulus kepada siswa agar siswa aktif bertanya. Hasil wawancara dengan guru di kelas rendah Mereka memberikan motivasi dan stimulus agara anak mau belajar yaitu dengan gambar, siswa kelas rendah menyukai cerita bergambar, menyukai warna dan bentuk-bentuk sehingga beliau sering memberikan gambar hewan ataupun tumbuhan menurut materi yang dipelajari dengan kertas hvs yang di tempel di papan, maka pandangan anak akan menuju kedepan. Cara memotivasi lain adalah dengan nyanyian, menampilkan video yang berhubungan dengan pembelajaran.

3. Kendala apa saja yang Bapak/Ibu alami dalam mengajar? jika ada kendala, apa solusinya?

Berdasarkan hasil analisis data wawancara yang dilakukan peneliti di lapangan yaitu di SDN 56 Banda Aceh, dapat disimpulkan bahwa masih banyak kendala dalam pembelajaran, setiap tingkat dan kelas mempunyai kendala yang berbeda. Guru juga mempunyai cara untuk mengatasi kendala yang ada. Di kelas rendah anak masih susah untuk di atur, terkadang mereka berlarian dan berdiri selama guru memberikan tugas, suara yang terkadang semakin membesar karena teriakan kadang tangisan, anak kurang tertib dan susah mengerti terhadap materi pembelajaran. solusinya guru harus lebih sering menegur dengan teguran anak menjadi terdiam dan teratur, memberikan pengulangan secara individu dan mengajarkan anak langsung ke papan tulis.

4. Berdasarkan aktivitas belajar siswa yang terjadi, apakah penelitian ini (dengan menggunakan teknik keterampilan bertanya ) sudah dapat dikatakan berhasil ? Menurut semua guru dari kelas 1 dan kelas 6 dengan menggunakan teknik keterampilan bertanya seorang guru sudah berhasil, Karena dapat meningkatkan minat dan motivasi siswa untuk aktif terlibat dalam belajar, merangsang siswa untuk menggali pengetahuan bagi dirinya. Siswa juga dapat mengembangkan kemampuan berpikir kritis dan bisa merangkum pelajaran yang telah diberikan, mendorong pemahaman mendalam dengan materi yang telah disampaikan, keterampilan bertanya juga membantu siswa menemukan hubungan antara ide serta selalu mengevaluasi kesulitan siswa dalam kegiatan belajar. 


\section{Pembahasan}

Adapun uraian pembahasan tentang Peranan Guru Dalam Menerapkan Keterampilan Bertanya di SD Negeri 56 Banda Aceh adalah sebagai berikut:

a. Pelaksanaan peranan guru dalam menerapkan keterampilan bertanya selama pembelajaran.

Pelaksanaan peranan guru dalam menerapkan keterampilan bertanya selama pembelajaran dapat di lihat dari tingkat kemampuan siswa dalam pembelajaran dengan tingkat di atas rata-rata, dan dapat dilihat dari segi fokusnya siswa dalam pembelajaran selama guru menjelaskan materi. Guru juga memberikan berbagai kreasi pembelajaran untuk meningkatkan aktivitas belajar di selingi pertanyaanpertanyaan yang telah dapat di jawab siswa walaupun memerlukan waktu dan dengan petunjuk guru. Menurut Roestiyah (2012:130) yang menyatakan bahwa dalam tanya jawab, guru bermaksud meneliti kemampuan/daya tangkap siswa untuk dapat memahami bacaan, apa mereka paham apa yang sedang dibacanya? Apakah siswa mengambil kesimpulan dari bacaannya ?. Pendapat tersebut di maksudkan untuk menilai kemampuan yang dimiliki siswa, dengan tanya jawab guru jadi tahu mana siswa yang sudah mengerti dan siswa yang belum mengerti.

b. Menerapkan keterampilan bertanya

Kegiatan siswa di SD Negeri 56 Banda Aceh telah melakukan penerapan keterampilan bertanya, hal tersebut dapat dilihat dari aktifnya siswa, selama pembelajaran setelah guru memberikan kesempatan berdiskusi, maka siswa kan berdiskusi dengan temannya. Jika ada yang belum dimengerti siswa, siswa tersebut bertanya dengan guru. Siswa juga mengajukan pendapatnya tentang materi yang sedang disampaikan, dan selama siswa memberikan tanggapan, siswa lainnya juga memperhatikan. Selama pertanyaan di sampaikan guru kepada siswa sebagian besar siswa sudah dapat merespon baik pertanyaan dari guru.

\section{c. Hambatan dan solusi}

Hambatan yang sering guru alami yaitu tidak fokusnya anak terhadap materi, ini di picu karena guru sering menggunakan metode ceramah. Dalam hal ini guru sering menyelingi suasana belajar dengan mengajukan pertanyaan. Kegiatan tersebut sebanding dengan hal yang diungkapkan oleh Sanjaya (2013:33) keterampilan bertanya bagi seorang guru merupakan keterampilan yang sangat penting untuk dikuasai. Sebab, melalui keterampilan ini guru menciptakan suasana pembelajaran lebih bermakna.

Dari aspek-aspek yang diamati disimpulkan bahwa menunjukkan bahwa aktivitas siswa dalam pembelajaran meningkat. Siswa banyak yang bertanya jika mengalami kesulitan dan tampak lebih semangat dalam kegiatan pembelajaran. Setiap siswa sudah terlihat tidak kebingungan dalam memecahkan masalah, keberanian siswa di kelas juga meningkat sehingga dalam proses pembelajaran yang berlangsung guru tidak lagi mendominasi pembelajaran. Pemahaman siswapun semakin bertambah akan materi yang diajarkan oleh guru.

\section{Simpulan}

Berdasarkan hasil penelitian yang telah dilakukan, maka peneliti menyimpulkan beberapa kesimpulan yang berkaitan dengan penelitian ini, yaitu:

a. Peranan guru dalam menerapkan keterampilan bertanya di SD Negeri 56 Banda Aceh sudah baik. Keterampilan bertanya juga dapat meningkatkan aktivitas belajar siswa. 
b. Hambatan dalam menerapkan keterampilan bertanya di SD Negeri 56 Banda Aceh yaitu kurangnya fokus siswa terhadap guru selama pembelajaran berlangsung akibat guru sering kali menerapkan metode ceramah yang begitu lama sehingga membuat siswa merasa bosan dan menghiraukan pelajaran. Pertanyaan yang baik akan membuat kelas menjadi interaktif, namun kesalahan dalam bertanya dapat menyebabkan pembelajaran tidak menarik.

c. Solusi yang digunakan SD Negeri 56 Banda Aceh untuk mengatasi hambatan dalam menerapkan keterampilan bertanya yaitu dengan seringnya membuat metode pembelajaran baru dengan diselingi pertanyaan dan menggunakan keterampilan bertanya di saat yang tepat selama pembelajaran. Mendekatkan diri kepada siswa sehingga tidak selalu membawa kelas ke dalam suasana serius saat menerapkan keterampilan bertanya, sehingga siswa merasa nyaman dan tidak takut untuk menjawabnya.

\section{Saran}

Saran yang dapat diberikan oleh peneliti adalah sebagai diharapkan kepada guru untuk menerapkan pembelajaran yang menarik dan menyenangkan sehingga dapat sehingga akan mendapat respon yang baik dan tidak merasa malu disaat menerapkan keterampilan bertanya.

\section{Referensi}

Gunawan, Imam. 2013. Metode Penelitian Kualitatif. Jakarta: PT Bumi Aksara. Hakim, Lukmanul. 2009. Perencanaan Pembelajaran. Bandung : Wacana Prima. Hasibuan, J.j. 2001. Proses Belajar Mengajar. Jakarta: PT Bumi Aksara.

Kamus Besar Bahasa Indonesia . (Online), (http://kbbi.web.id/tanya., diakses 29 februari 2017)

Majid, Abdul. 2012. Keterampilan Bertanya. (Online), (http ://www. tintapendidikanindonesia.com/2016/12/keterampilanbertanya. html diakses 12 Maret 2017)

Moleong, Lexi J. 2010. Analisis Data Kualitatif. (Online). (journal. repository.upi.edu/11140/6/S_PLS_0907078_Chapter3.pdf., diakses 28 Maret 2017).

Mulyasa.2006. Menjadi Guru Profesional. Bandung: Remaja Rosda Karya.

Noor, Juliansyah. 2013. Metode Penelitian. Jakarta: Kencana Prenada Media Group.

Risovi, Zulhani. 2014. Keterampilan Bertanya Guru Dalam Meningkatkan Aktivitas Belajar Siswa Pada Mata Pelajaran Fiqih(Online). (journal.amikom.ac.id,risovi,zulhani diakses 29 Februari 2017)

Roestiyah. 2012. Strategi Belajar Mengajar. Jakarta: PT Rineka Cipta

Sanjaya, Wina. 2016. Strategi Pembelajaran Berorientasi Standar Proses Pendidikan. Jakarta: PT Kencana

Soetopo, Hendayat. 2005. Pendidikan \& Pembelajaran. Malang : Universitas Muhammadiyah Malang

Sugiyono. 2015. Metode Penelitian Pendidikan (Pendekatan Kuantitatif,Kualitatif, danR\&D). Bandung: Alfabeta.

Usman, Husaini. Setiady Akbar. 2014. Metode Penelitian Sosial. Jakarta: PT Bumi Aksara.

Yani, Ahmad. 2013. 12 Keterampilan Dasar Mengajar. Jakarta : CV. Pringgadani

Zuriah, Nurul. 2009. Metodelogi Penelitian Sosialdan Pendidikan. Jakarta: PT Bumi Aksara 